\title{
Diversity and ecology of desmids of peat bogs in the Jeseníky Mts: spatial distribution, remarkable finds
}

\author{
Jana ŠTĚPÁnKovÁ A $^{1,2}$, Petr HašLer ${ }^{1}$, Martina HladKÁ ${ }^{2} \&$ Aloisie PoulíčKovÁ $^{1}$ \\ ${ }^{1}$ Department of Botany, Faculty of Science, Palacký University, 17. listopadu 12, CZ-771 46 Olomouc, Czech \\ Republic; e-mail: jana.stepankova@upol.cz, aloisie.poulickova@upol.cz \\ ${ }^{2}$ Department of Biology, Faculty of Education, Palacký University, Purkrabská 2, CZ-779 00 Olomouc, Czech \\ Republic
}

\begin{abstract}
Diversity and ecology of desmids (Zygnematophyceae) were studied within eight peat bog sites in the Jeseníky Mts during the years 2006-2009. Altogether, 51 taxa were found in the course of our investigation. A detailed study of spatial distribution of desmids in relation to environmental characteristics was performed. The composition of desmid communities was influenced especially by water table elevation and $\mathrm{pH}$. Among all chemical substances measured and statistically tested, $\mathrm{Mg}, \mathrm{Ca}$ and $\mathrm{Pb}$ concentrations appeared to have a considerable effect. Several remarkable desmid taxa were found and discussed in terms of their occurrence and broad morphological variability.
\end{abstract}

Key words: desmids, diversity, environmental gradients, Jeseníky Mts, peat bogs

\section{Introduction}

As ecosystems with a relict and island character, mountain bogs belong to the most valuable and threatened biotopes in Central Europe (CHARMAN 2002; BEZDĚK et al. 2006). From the viewpoint of nature conservation and science, each of these more or less isolated biotopes is of great importance namely to preservation of ecologically distinctive organisms and communities and, in addition, as a place with potential for further evolution of this diversity (allopatric speciation).

In the Jeseníky Mts (North Moravia, Czech Republic), there are several relatively good preserved bogs harbouring rare flora and fauna. They are mostly strictly protected within National Nature Reserves (KoleKtiv AUtORŮ 2003). Recently, they have become objects of intensive ecological research aiming to evaluate changes in mire ecosystems of the Sudetes mountain belt induced by long-term exposure to air contamination and draining, especially during the second half of the $20^{\text {th }}$ century (RYBNičEK 2003). Since 1994, a continuous monitoring of bog vegetation and environmental variables has been in progress in the Jeseníky Mts. Contrary to other regions in the Sudetes, they seem to be less affected (RYBNiČEK 1997, 2003). However, the knowledge on microorganisms diversity is generally very poor, in spite of their important role in the assessment of the state and dynamics of mire ecosystems (Coesel 1998; Mitchell et al. 2008). Just a few old algological analyses (FisCHER 1924, 1925; LHOTSKÝ 1949; RYBNÍČEK 1958) are at disposal from mountain bogs in this region. Thus, there has been a strong need for a recent systematic ecological investigation of algal communities. The presented study focuses on desmids (Zygnematophyceae) as a very characteristic and (co)dominant group in bog water microflora. Because of their high ecological sensitivity to environmental changes, they are generally considered to be useful bioindicators (Coesel 1998, 2001, 2003).

\section{Localities}

We involved eight mires (Fig. 1, Table 1) in our study which have the character of acidic oligoombrotrophic mountain raised bogs. They are concentrated in three areas: the Praděd NNR (localities Máj, Slatě, Barborka), the ŠerákKeprník NNR (localities Trojmezí A, Trojmezí B, Vozka, Sedlo pod Vozkou) (RYBNí́̌EK 1997) and the Rejvíz NNR (locality Rejvíz). Most of the mires have been developing in flat saddles or shallow depressions of the extensive summit 
plains (1300-1360 m a.s.1.) since the Atlantic period (KoleKTIV AUTORŮ 2003). The treeless bog centres are mostly covered by typical vegetation with extensive Sphagnum carpets, Eriophorum vaginatum $\mathrm{L}$. and dwarf shrublets, namely Oxycoccus palustris Pers., Calluna vulgaris (L.) Hull., Vaccinium uliginosum L. and V. myrtillus L., some sites are notable for Andromeda polifolia L. and Empetrum hermaphroditum HaGerup. These bog parts include several pools of various sizes characterized by the presence of Carex limosa L., Eriophorum angustifolium HonCK. and Drepanocladus fluitans (Hedw.) WARnst. (RYBNíčEK 1997). In most cases, the bog margins are occupied by extensive stands of Picea abies (L.) KaRsten.

Among the studied localities, the Rejvíz bog has an exceptional character. Contrary to the summit bogs in the vicinity of Praděd and ŠerákKeprník, it is situated at a lower altitude (734-794 $\mathrm{m}$ a.s.1.), rather geographically isolated from

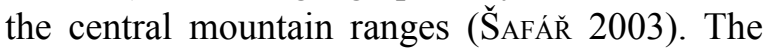
investigated bog centre is just a part of a vast mire complex comprising raised and transitional bogs, fen and waterlogged meadows, bog spruce forests and unique bog pine stands with Pinus rotundata

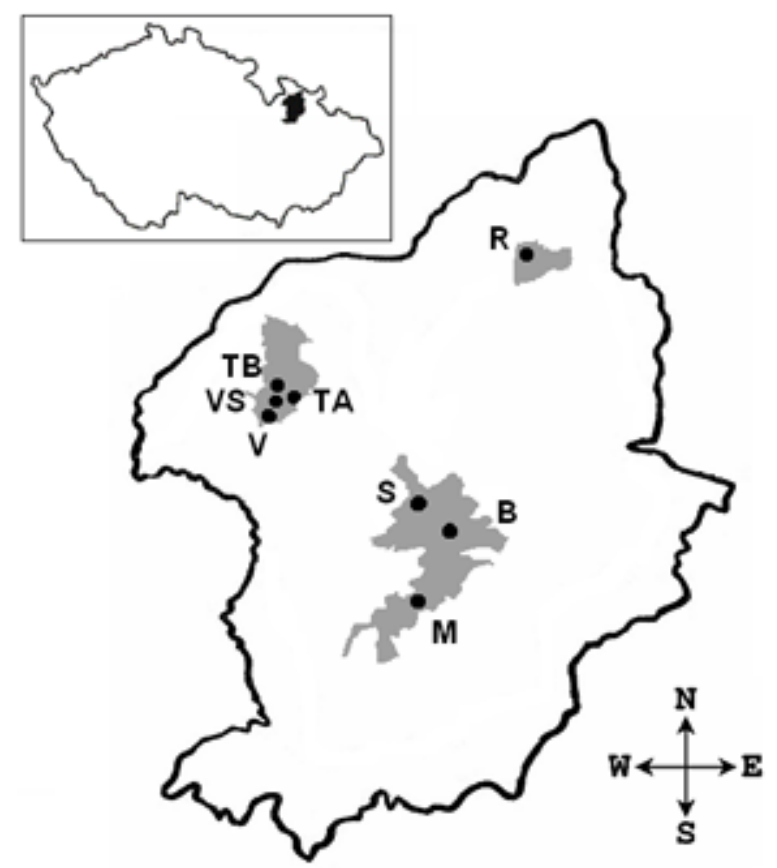

Fig. 1. Location of the investigated bogs in the Jeseníky Mts (Czech Republic) [abbreviations of bogs: (B) Barborka, (M) Máj, (R) Rejvíz, (S) Slatě, (TA) Trojmezí A, (TB) Trojmezí B, (V) Vozka, (VS) Sedlo pod Vozkou. Grey patches represent the areas of the respective National Nature Reserves (mentioned in the text)].
LINK and Ledum palustre L. surrounding two bog lakes (KoLEKTIV AUTORŮ 2003; ŠAFÁŘ 2003).

\section{Material and Methods}

Samples for investigation were collected in autumn 2006, summer 2008 and spring 2009. Within the eight bogs described above, altogether 30 permanent sample plots were delimited (RYBNí̌̌EK 1997, 2003) (Table 1). Number of plots per locality (2-5) corresponds with the size of the respective bog. The sample plots represent main microhabitats and vegetation types occurring in summit bogs of the Jeseníky Mts. Regarding the microtopography, we distinguished flat lawns (relatively dry sites with continuous vegetation cover), forests (lawns with scattered spruce or pine trees), bog pools and one bog lake (the Great Moss Lake within the Rejvíz bog). In relation to phytocenology, RYBNí̌̌EK (1997) recognized two associations: (a) Drepanoclado fluitantis-Caricetum limosae (KäsTNER et FlösSNER) KRISAI with 4 successional stages (subassociations) of bog pools vegetation and (b) Andromedo polifoliaeSphagnetum magellanici (BogdanovskaJA-Gienev) NeUHäUSL with 4 successional stages of most of the lawn sites. Plots within the bog pine stands of the Rejvíz mire represent vegetation of Pino rotundataeSphagnetum (KäSTNER et FlössNer) NeuHÄUSL (ŠAfÁ̌̆ 2003).

From each permanent plot, mixed samples were obtained by squeezing or scraping off bog vegetation (especially Sphagnum spp.), collecting submerged algal growths, plankton and epipelon from peat bog pools. They were fixed with formaldehyde (final concentration 2\%). Both fixed and fresh samples were examined using the light microscope Olympus BX51. The desmid taxa were determined according to RƯŽIČKA (1977, 1981), Coesel (1982, 1983, 1985, 1991, 1994, 1997) and Lenzenweger (1996, 1997, 1999, 2003). The abundance of particular desmid taxa was assessed according to the following semi-quantitative scale: 0 - absent; 1 - very rare; 2 - scattered; 3 - common; 4 - predominant.

At the time of the algological sampling, water table elevation was measured and bog waters were sampled from natural pools or small artificial pits at each of the permanent plots. Water samples were analysed for important physico-chemical variables. Electric conductivity and $\mathrm{pH}$ were measured with Greisinger GMH 3410 Conductometer and Greisinger GMH 1410 $\mathrm{pH}$ meter in the laboratory of the Department of Botany and Zoology (Faculty of Science, Masaryk University, Brno). Soluble humic substances, contents of major ions $\left(\mathrm{NH}_{4}^{+}, \mathrm{NO}_{2}^{-}, \mathrm{NO}_{3}^{-}, \mathrm{SO}_{4}^{2-}, \mathrm{PO}_{4}^{3-}, \mathrm{Cl}^{-}, \mathrm{Na}^{+}, \mathrm{Ca}^{2+}, \mathrm{Mg}^{2+}\right)$ and some metals $(\mathrm{Zn}, \mathrm{Mn}, \mathrm{Fe}, \mathrm{Al}, \mathrm{Pb})$ were analysed at the Department of Hydrochemistry (T.G. Masaryk Water Research Institute, Brno). Electric conductivity values were corrected for the effect of hydrogen ions 
Table 1. Main geographical and environmental characteristics of the investigated mountain bogs. Geographical characteristics are presented according to RYBNíČEK (1997) and ŠAFÁr (2003). Data on physico-chemical parameters are related to the sampling in summer 2008 [abbreviations: (WTE) water table elevation, (EC) electric conductivity, (d) discontinuous].

\begin{tabular}{|c|c|c|c|c|c|c|c|}
\hline $\begin{array}{l}\text { Locality/GPS } \\
(\mathrm{N} / \mathrm{E})\end{array}$ & $\begin{array}{l}\text { Altitude } \\
\text { (m a.s.l.) }\end{array}$ & $\begin{array}{l}\text { Area } \\
\text { (ha) }\end{array}$ & $\begin{array}{l}\text { Sample plot } \\
\text { (type, number) }\end{array}$ & $\begin{array}{l}\text { WTE } \\
(\mathrm{cm})\end{array}$ & $\mathrm{pH}$ & $\begin{array}{c}\text { EC } \\
\left(\mu{\left.\mathrm{S} . \mathrm{cm}^{-1}\right)}^{-1}\right.\end{array}$ & $\begin{array}{l}\mathrm{Mg}^{2+} \\
\left(\mathrm{mg} \cdot \mathrm{l}^{-1}\right)\end{array}$ \\
\hline \multirow{3}{*}{$\begin{array}{l}\text { Máj } \\
50^{\circ} 02^{\prime} 55^{\prime}{ }^{\prime} \mathrm{N} ; 17^{\circ} 13^{\prime} 05^{\prime} \mathrm{E}\end{array}$} & \multirow[t]{3}{*}{1360} & \multirow[t]{3}{*}{$2-3 \mathrm{~d}$} & forest, 01 & -14 & 4.16 & 23 & 0.11 \\
\hline & & & lawn, 02 & -16 & 4.13 & 25 & 0.01 \\
\hline & & & lawn, 03 & -15 & 4.27 & 13 & 0.13 \\
\hline \multirow{2}{*}{$\begin{array}{l}\text { Barborka } \\
50^{\circ} 04^{\prime} 30^{\prime \prime} \mathrm{N} ; 17^{\circ} 13^{\prime} 50^{\prime \prime} \mathrm{E}\end{array}$} & \multirow[t]{2}{*}{1305} & \multirow[t]{2}{*}{0.5} & pool, 04 & 0 & 3.90 & 20 & 0.11 \\
\hline & & & lawn, 05 & -10 & 3.88 & 19 & 0.19 \\
\hline \multirow{4}{*}{$\begin{array}{l}\text { Slatě } \\
50^{\circ} 06^{\prime} 15^{\prime \prime} \mathrm{N} ; 17^{\circ} 12^{\prime} 35^{\prime \prime} \mathrm{E}\end{array}$} & \multirow[t]{4}{*}{1310} & \multirow[t]{4}{*}{2.0} & lawn, 06 & -10 & 3.95 & 16 & 0.11 \\
\hline & & & forest, 07 & -5 & 3.83 & 23 & 0.16 \\
\hline & & & lawn, 08 & -8 & 3.85 & 14 & 0.15 \\
\hline & & & lawn, 09 & -6 & 3.79 & 30 & 0.13 \\
\hline \multirow{4}{*}{$\begin{array}{l}\text { Rejvíz } \\
50^{\circ} 13^{\prime} 11^{\prime \prime N} ; 17^{\circ} 17^{\prime} 13^{\prime \prime} \mathrm{E}\end{array}$} & \multirow[t]{4}{*}{764} & \multirow[t]{4}{*}{325} & bog lake, 10 & 0 & 3.82 & 26 & 0.07 \\
\hline & & & forest, 11 & -20 & 3.74 & 35 & 0.10 \\
\hline & & & forest, 12 & -10 & 3.65 & 40 & 0.16 \\
\hline & & & lawn, 13 & 0 & 3.76 & 22 & 0.20 \\
\hline \multirow{5}{*}{$\begin{array}{l}\text { Trojmezí A } \\
50^{\circ} 09^{\prime} 45^{\prime \prime} \mathrm{N} ; 17^{\circ} 07^{\prime} 15^{\prime \prime} \mathrm{E}\end{array}$} & \multirow[t]{5}{*}{1300} & \multirow[t]{5}{*}{0.5} & pool, 14 & -4 & 5.29 & 19 & 1.14 \\
\hline & & & lawn, 15 & -15 & 5.00 & 21 & 1.10 \\
\hline & & & pool, 16 & 0 & 4.79 & 20 & 0.80 \\
\hline & & & pool, 17 & 0 & 4.58 & 21 & 0.90 \\
\hline & & & lawn, 18 & -4 & 4.58 & 22 & 1.10 \\
\hline \multirow{5}{*}{$\begin{array}{l}\text { Trojmezí B } \\
50^{\circ} 09^{\prime} 50^{\prime} \mathrm{N} ; 17^{\circ} 07^{\prime} 05^{\prime} \mathrm{E}\end{array}$} & \multirow[t]{5}{*}{1315} & \multirow[t]{5}{*}{0.7} & lawn, 19 & -7 & 4.20 & 17 & 0.30 \\
\hline & & & pool, 20 & 0 & 4.19 & 16 & 0.73 \\
\hline & & & lawn, 21 & -10 & 4.11 & 15 & 0.51 \\
\hline & & & lawn, 22 & -9 & 4.01 & 19 & 0.58 \\
\hline & & & pool, 23 & 0 & 4.22 & 13 & 0.40 \\
\hline \multirow{2}{*}{$\begin{array}{l}\text { Sedlo pod Vozkou } \\
50^{\circ} 09^{\prime} 40^{\prime \prime} \mathrm{N} ; 17^{\circ} 06^{\prime} 45^{\prime \prime} \mathrm{E}\end{array}$} & \multirow[t]{2}{*}{1305} & \multirow[t]{2}{*}{0.4} & pool, 24 & 0 & 4.02 & 22 & 0.39 \\
\hline & & & lawn, 25 & -13 & 4.03 & 15 & 0.31 \\
\hline \multirow{5}{*}{$\begin{array}{l}\text { Vozka } \\
50^{\circ} 09^{\prime} 30^{\prime \prime} \times ; 17^{\circ} 06^{\prime} 30^{\prime \prime} \mathrm{E}\end{array}$} & \multirow[t]{5}{*}{1325} & \multirow[t]{5}{*}{8.0} & lawn, 26 & -14 & 4.01 & 25 & 0.43 \\
\hline & & & pool, 27 & 0 & 4.72 & 21 & 1.00 \\
\hline & & & lawn, 28 & -7 & 4.22 & 25 & 0.33 \\
\hline & & & pool, 29 & 0 & 4.14 & 20 & 0.52 \\
\hline & & & pool, 30 & 0 & 4.06 & 24 & 0.45 \\
\hline
\end{tabular}

by means of subtraction of conductivity caused by $\mathrm{H}^{+}$ (SJÖRS 1952).

Data on the physico-chemical characteristics and desmid taxa abundances related to the sampling in summer 2008 were analysed by multivariate statistical methods using the programme CANOCO (TER BRAAK
\& ŠMilauer 1998). At first, algological data were analysed by detrended correspondence analysis (DCA). Lengths of gradient indicated, that unimodal ordination methods are less applicable to the data set, so linear methods (PCA, RDA) were then used. 

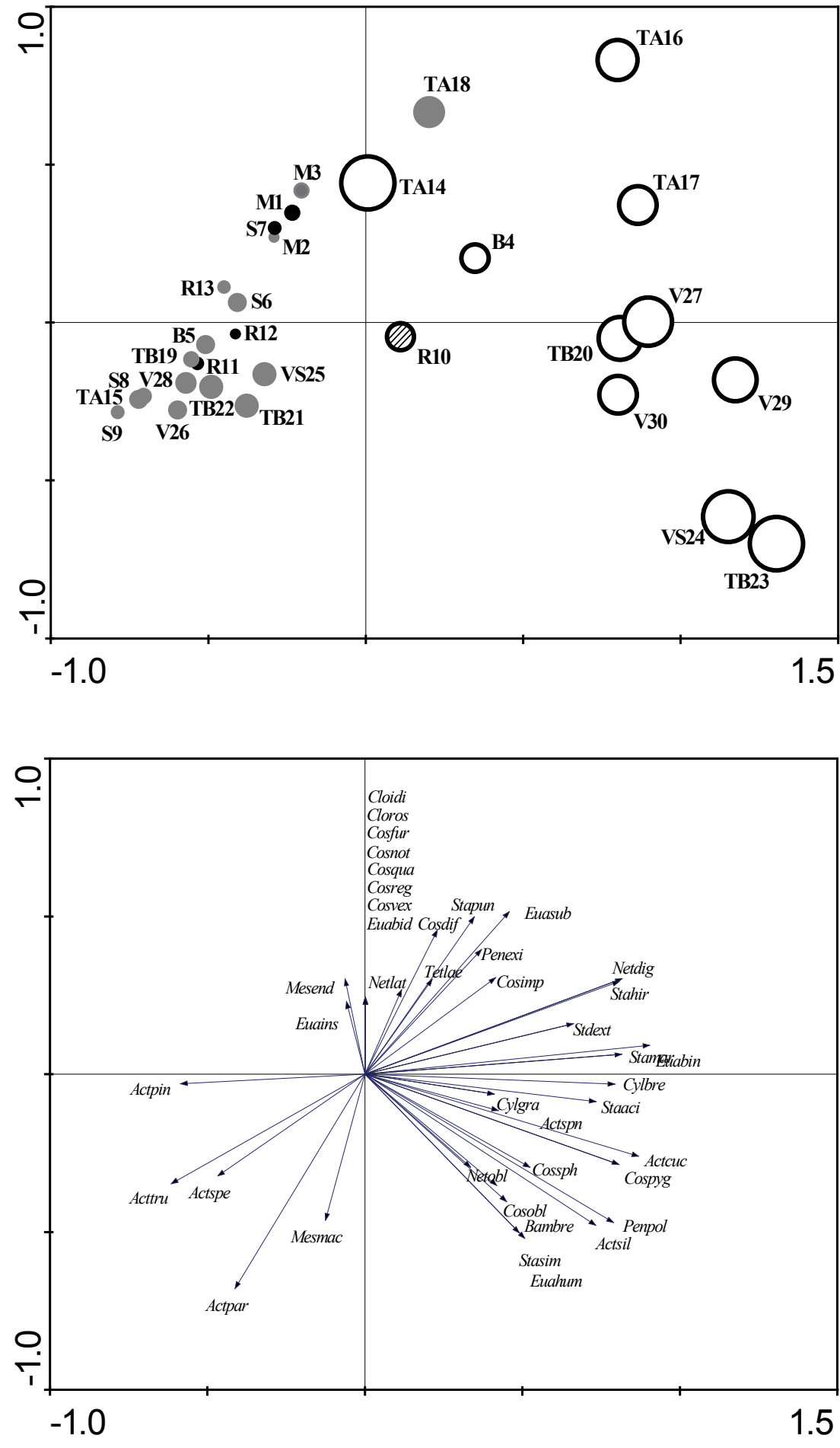

Fig. 2a. PCA diagram of 30 sample plots according to their species composition on the first two ordination axes. The size of symbols correlates with desmid diversity of the respective plots: 4-21 taxa [(Black circles) forest plots, (grey circles) lawns, (white circles) pools, (hatched circle) bog lake; abbreviations of bogs: (B) Barborka, (M) Máj, (R) Rejvíz, (S) Slatě, (TA) Trojmezí A, (TB) Trojmezí B, (V) Vozka, (VS) Sedlo pod Vozkou].

\section{Ecological Part}

\section{Results}

During our study (2006-2009), altogether 51 desmid taxa (Table 3) were found in eight bog localities of the Jeseníky Mts. Most of them are known as oligotrophic, acidophilic algae. So, their occurrence is fully in accordance with the type of habitats (raised bogs). The most frequent taxa (found in the most localities) were Actinotaenium cucurbita, A. pinicolum, A. silvae-nigrae var. parallelum, A. cf. truncatum, Cosmarium sp., Cylindrocystis brebissonii, Euastrum binale var. gutwinskii, Mesotaenium macrococcum, Netrium digitus, Staurastrum furcatum var. aciculiferum and $S$. margaritaceum. A detailed study of spatial distribution of desmids in relation to environmental characteristics was performed in several steps. 

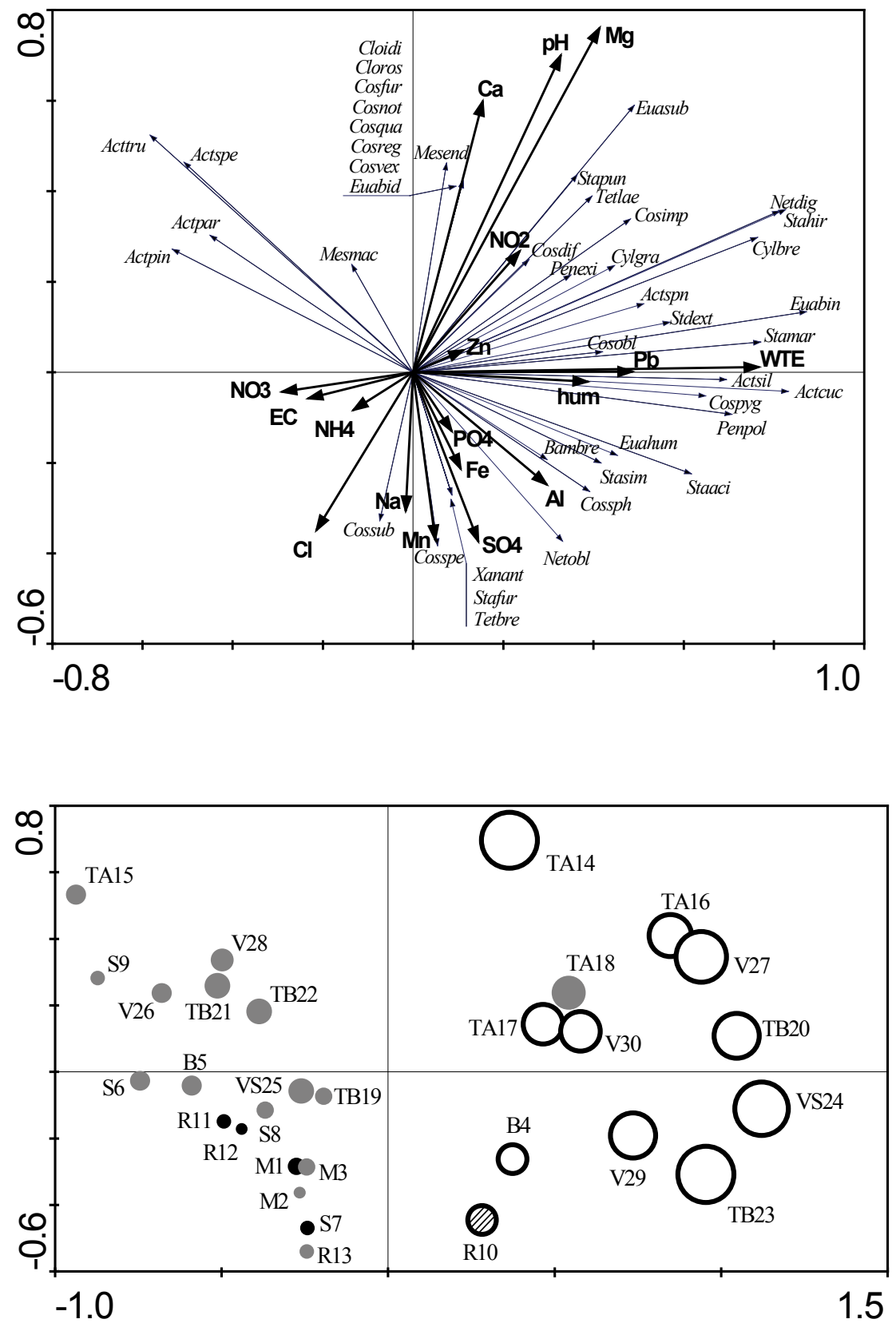

Fig. 3a. RDA diagram showing linear responses of desmid species to environmental gradients [abbreviations of environmental variables: (EC) electric conductivity, (hum) humic substances, (WTE) water table elevation. Only well fitting species are displayed. For the species abbreviations see Table 3].

Fig. 3b. RDA ordination of 30 sample plots based on species variation related to environmental gradients. (Positions of the respective vectors and desmid distribution are displayed in Fig. 3a.) The size of symbols correlates with desmid diversity of the respective plots: 4-21 taxa [(Black circles) forest plots, (grey circles) lawns, (white circles) pools, (hatched circle) bog lake; abbreviations of bogs: (B) Barborka, (M) Máj, (R) Rejvíz, (S) Slatě, (TA) Trojmezí A, (TB) Trojmezí B, (V) Vozka, (VS) Sedlo pod Vozkou].
Principal component analysis (PCA) was performed to reveal the overall structure of species data (Figs 2a, b). Along the first ordination axis (reflecting $42 \%$ of the entire variability), species composition of sample plots changes primarily with the water table elevation. Relatively dry, species-poor (4-9 desmid taxa) lawns and forests are clearly separated from pools with higher desmid diversity (11-21 taxa). Nevertheless, one lawn plot (TA18) is placed rather in the group of pool-samples. The species composition of TA18 was influenced by intensive waterlogging and by a pool in the immediate vicinity. It was marked by occurrence of desmids that were often found in bog pools and absent at most of the relatively dry sites (Euastrum binale var. gutwinskii, Euastrum subalpinum, Netrium digitus, Staurastrum hirsutum). On the contrary, one of the pools (TA14) has a position near the group of lawn-samples. It reflects well the character of this sample plot, which comprised of a small pool with adjacent Sphagnum growth, and so combined the typically aquatic desmids with the subatmophytic ones. In the ordination diagram (Fig. 2a), forest plots are scattered among lawn plots suggesting that the presence of a (sparse) tree layer does not cause any substantial changes in desmid assemblages regarding the relatively dry 
Table 2. Effects of physico-chemical variables on desmid distribution among the sample plots resulting from the RDA (Monte Carlo test; 499 permutations). Eigenvalue of the first canonical axis $(\lambda 1), F-$ ratio values $(F)$ and corresponding probability values $(\mathrm{P})$ are given. Significant $\mathrm{P}$ values $<0.02$ [abbreviations of physico-chemical variables: (EC) electric conductivity, (hum) humic substances, (WTE) water table elevation].

\begin{tabular}{llllllll}
\hline \multicolumn{2}{l}{ Marginal effects } & \multicolumn{7}{l}{ Conditional effects } \\
\hline Variable & $\lambda 1$ & $\mathrm{P}$ & $\mathrm{F}$ & Variable & $\lambda 1$ & $\mathrm{P}$ & $\mathrm{F}$ \\
$\mathrm{WTE}$ & 0.23 & 0.002 & 8.19 & $\mathrm{WTE}$ & 0.23 & 0.002 & 8.19 \\
$\mathrm{Mg}^{2+}$ & 0.12 & 0.008 & 3.88 & $\mathrm{pH}$ & 0.08 & 0.004 & 3.12 \\
$\mathrm{~Pb}$ & 0.11 & 0.012 & 3.40 & $\mathrm{~Pb}$ & 0.07 & 0.002 & 3.08 \\
$\mathrm{pH}$ & 0.10 & 0.014 & 3.14 & $\mathrm{NO}_{2}^{-}$ & 0.05 & 0.026 & 2.20 \\
$\mathrm{hum}$ & 0.07 & 0.052 & 2.13 & $\mathrm{Mg}^{2+}$ & 0.04 & 0.100 & 1.58 \\
$\mathrm{Ca}^{2+}$ & 0.06 & 0.102 & 1.75 & $\mathrm{hum}$ & 0.02 & 0.248 & 1.26 \\
$\mathrm{Al}^{-}$ & 0.05 & 0.194 & 1.40 & $\mathrm{EC}^{-}$ & 0.04 & 0.100 & 1.62 \\
$\mathrm{Cl}^{-}$ & 0.04 & 0.288 & 1.22 & $\mathrm{Al}^{-}$ & 0.03 & 0.212 & 1.28 \\
$\mathrm{NO}_{2}^{-}$ & 0.04 & 0.326 & 1.12 & $\mathrm{Cl}^{-}$ & 0.02 & 0.256 & 1.24 \\
$\mathrm{NO}_{3}^{-}$ & 0.04 & 0.380 & 1.04 & $\mathrm{NH}_{4}^{+}$ & 0.03 & 0.240 & 1.23 \\
$\mathrm{EC}^{-}$ & 0.03 & 0.396 & 0.95 & $\mathrm{Mn}^{+}$ & 0.02 & 0.392 & 1.01 \\
$\mathrm{Na}^{+}$ & 0.03 & 0.454 & 0.91 & $\mathrm{SO}_{4}^{2-}$ & 0.02 & 0.488 & 0.92 \\
$\mathrm{PO}_{4}^{3-}$ & 0.03 & 0.492 & 0.89 & $\mathrm{Zn}^{3-}$ & 0.01 & 0.552 & 0.87 \\
$\mathrm{Mn}^{-}$ & 0.03 & 0.496 & 0.85 & $\mathrm{PO}_{4}^{3-}$ & 0.02 & 0.648 & 0.76 \\
$\mathrm{SO}_{4}^{2-}$ & 0.03 & 0.546 & 0.80 & $\mathrm{Fe}^{2-}$ & 0.02 & 0.550 & 0.85 \\
$\mathrm{Zn}^{-}$ & 0.03 & 0.552 & 0.77 & $\mathrm{NO}_{3}^{-}$ & 0.01 & 0.860 & 0.47 \\
$\mathrm{Fe}^{-}$ & 0.02 & 0.650 & 0.69 & $\mathrm{Ca}^{2+}$ & 0.01 & 0.864 & 0.50 \\
$\mathrm{NH}_{4}^{+}$ & 0.02 & 0.678 & 0.67 & $\mathrm{Na}^{+}$ & 0.01 & 0.882 & 0.45 \\
\hline
\end{tabular}

sites. One of the most distinctive plots under the study was the Great Moss Lake (R10) within the Rejvíz bog, harbouring one of the poorest desmid assemblages among the aquatic sites composed of typical acidophilic, oligotrophic taxa. It can probably be related to strong acidity of the water (seasonal decrease in $\mathrm{pH}$ to 3.2), and to exceptional character of this aquatic site - large and deep bog lake (blänk). The latter factor can explain e.g. the isolated occurrence of a benthic-planktic desmid Xanthidium antilopaeum var. laeve (Coesel 1998; ŠŤASTNÝ 2010; see also Figs 3a, b).

The redundancy analysis (RDA) was performed to obtain the information about linear response of desmid species to environmental gradients (Figs 3a, b). As explanatory variables, 18 physico-chemical factors were entered (water table elevation, $\mathrm{pH}$, conductivity, humic substances, $\mathrm{Ca}^{2+}, \mathrm{Mg}^{2+}, \mathrm{Na}^{+}, \mathrm{Cl}^{-}, \mathrm{Fe}, \mathrm{Zn}, \mathrm{Mn}$, $\left.\mathrm{Al}, \mathrm{Pb}, \mathrm{NO}_{2}^{-}, \mathrm{NO}_{3}^{-}, \mathrm{NH}_{4}^{+}, \mathrm{SO}_{4}^{2-}, \mathrm{PO}_{4}^{3-}\right)$. The first canonical axis includes nearly $38 \%$ of the variability in species data and is highly significant ( $\mathrm{P}=0.004$; 499 Monte Carlo permutations). The water table elevation, strongly correlated with the first axis, was confirmed to be the leading factor for desmids distribution (Fig. 3a, Table 2). It reflects the well known fact that the most desmid taxa prefer or require the presence of a water body in the bog environment. This tendency was particularly evident in distribution of Actinotaenium cucurbita, A. silvae-nigrae, Cosmarium pygmaeum, Euastrum binale var. gutwinskii, E. subalpinum, Netrium digitus, Penium polymorphum, Staurastrum furcatum var. aciculiferum, S. hirsutum, S. margaritaceum, $S$. punctulatum and Staurodesmus extensus var. isthmosus. On the contrary, just a few desmids (Actinotaenium pinicolum, A. silvae-nigrae var. parallelum, A. cf. truncatum, Actinotaenium sp.) were most abundant at the relatively dry sites. This species group may seem to slightly correlate with the growing conductivity and $\mathrm{NO}_{3}^{-}$concentration 


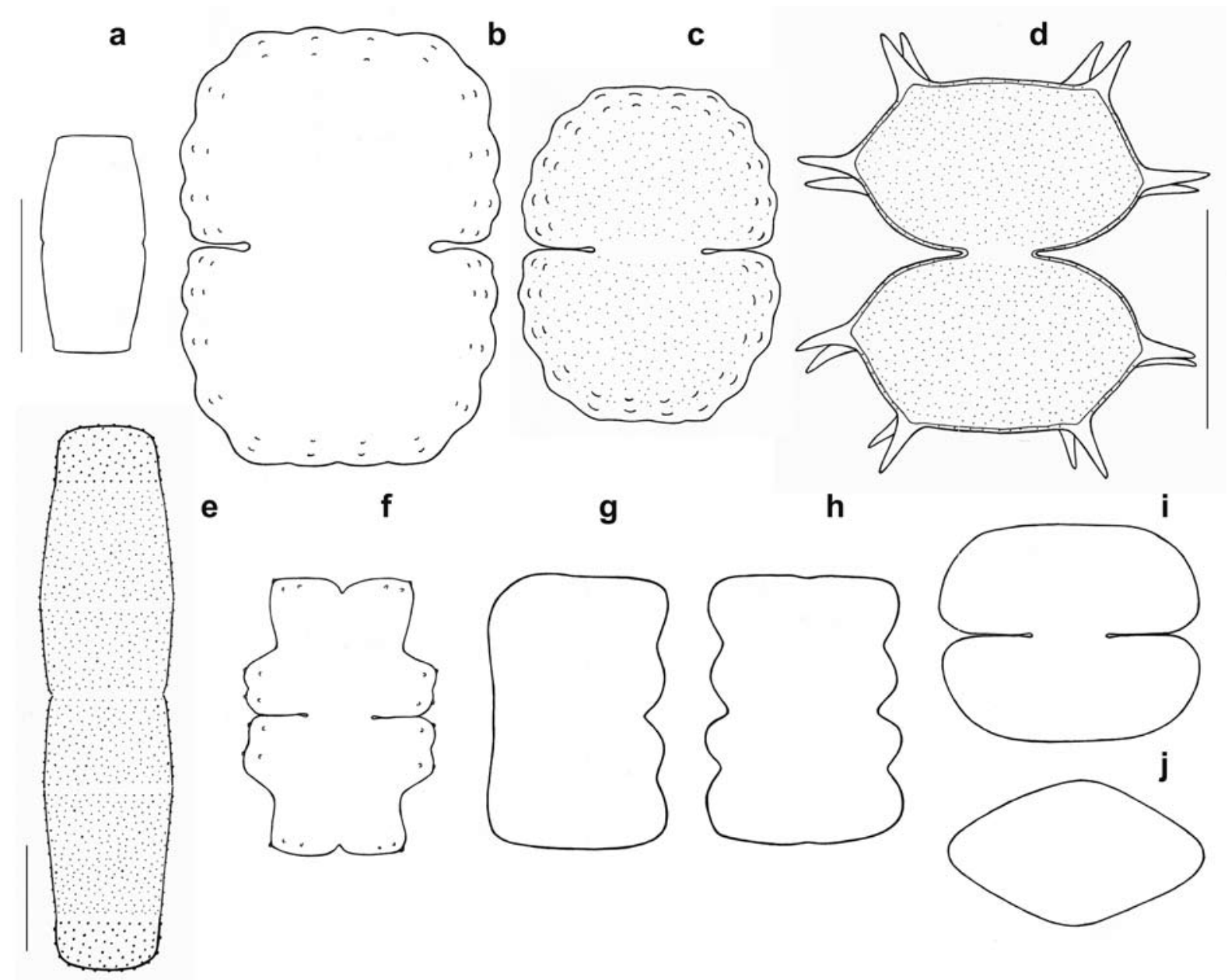

Fig. 4. Remarkable desmid taxa found in the mountain bogs of the Jeseníky Mts: (a) Actinotaenium pinicolum; (b) Cosmarium notabile; (c) Cosmarium cf. furcatospermum; (d) Xanthidium antilopaeum var. laeve; (e) Penium exiguum; (f) Euastrum subalpinum; (g) Cosmarium obliquum cf. var. tatricum, side view; (h) Cosmarium obliquum cf. var. tatricum, front view; (i) Cosmarium subquadrans var. minor, front view; (j) Cosmarium subquadrans var. minor, top view. Scale bar $10 \mu \mathrm{m}, 50 \mu \mathrm{m}$ (for d).

in the ordination diagram (Fig. 3a), but in fact, it reflects a negative relation to the water content. In Fig. 3b, particular samples (permanent plots) are divided into a lawn/forest group and a group of aquatic sites, following the humidity gradient (the vector position displayed in Fig. 3a). Surprisingly, another variable showing a strong correlation with the first ordination axis was the concentration of $\mathrm{Pb}$. Both marginal and conditional effects of $\mathrm{Pb}$ on desmid distribution were evaluated as significant by the RDA (Table 2) and will be discussed below.

The second canonical axis $(9 \%$ of the species variation) can be interpreted as a simultaneous increase of $\mathrm{pH}, \mathrm{Ca}$ and $\mathrm{Mg}$, whose vector positions show an intercorrelation in the RDA diagram (Fig. 3a). The effect of $\mathrm{pH}$ on desmid distribution was significant (see Table 2). Also $\mathrm{Mg}$ had a considerable influence on species composition of sample plots. However, statistically it only refers to its marginal effect, which is strengthened by correlated variables (above all $\mathrm{pH}$ and $\mathrm{Ca}$ ). In an ordination model with other physico-chemical factors as covariables, the effect of $\mathrm{Mg}$ lost its significance (Table 2). Two species groups were distinctly connected with the $\mathrm{pH}, \mathrm{Ca}$ and $\mathrm{Mg}$ increase. (I) The occurrence of Euastrum bidentatum, Cosmarium vexatum, $C$. regnellii, $C$. quadratum, C. notabile, C. cf. furcatospermum, Closterium rostratum, $\mathrm{Cl}$. cf. idiosporum and partially Mesotaenium endlicherianum was focused on TA14 (a pool within the Trojmezí A bog) characterized by the highest $\mathrm{pH}, \mathrm{Ca}$ and Mg values among all sites under the study (Figs 3a, b). (II) Euastrum subalpinum, Staurastrum punctulatum and Tetmemorus laevis displayed a 
Table 3. List of desmid taxa recorded in peat bogs of the Jeseníky Mts during the investigation in 2006-2009 [abbreviations of peat bogs: (B) Barborka, (M) Máj, (R) Rejvíz, (S) Slatě, (TA) Trojmezí A, (TB) Trojmezí B, (V) Vozka, (VS) Sedlo pod Vozkou].

\begin{tabular}{|c|c|c|}
\hline Taxon & Abbreviation & Locality \\
\hline Actinotaenium cucurbita (BRÉB.) TeILING & Actcuc & $\mathrm{M}, \mathrm{B}, \mathrm{R}, \mathrm{TA}, \mathrm{TB}, \mathrm{VS}, \mathrm{V}$ \\
\hline Actinotaenium pinicolum RosA & Actpin & $\mathrm{M}, \mathrm{B}, \mathrm{S}, \mathrm{R}, \mathrm{TA}, \mathrm{TB}, \mathrm{VS}, \mathrm{V}$ \\
\hline $\begin{array}{l}\text { Actinotaenium silvae-nigrae var. silvae-nigrae (RABANUS) } \\
\text { KouwETS et COESEL }\end{array}$ & Actsil & $\mathrm{R}, \mathrm{TB}, \mathrm{VS}, \mathrm{V}$ \\
\hline $\begin{array}{l}\text { Actinotaenium silvae-nigrae var. parallelum (KRIEGER) } \\
\text { KouwETS et COESEL }\end{array}$ & Actpar & $\mathrm{M}, \mathrm{B}, \mathrm{S}, \mathrm{R}, \mathrm{TA}, \mathrm{TB}, \mathrm{VS}, \mathrm{V}$ \\
\hline Actinotaenium cf. spinospermum (JoshuA) Kouwets et Coesel & Actspn & TB, VS, V \\
\hline Actinotaenium cf. truncatum (BRÉB.) TeILING & Acttru & B, S, R, TA, TB, VS, V \\
\hline Actinotaenium sp. & Actspe & $\mathrm{S}, \mathrm{TA}, \mathrm{TB}, \mathrm{V}$ \\
\hline Bambusina brebissonii KüTz. ex KüTz. & Bambre & $\mathrm{B}, \mathrm{TA}, \mathrm{TB}, \mathrm{V}$ \\
\hline Closterium cf. idiosporum WEST et G. S. WEST & Cloidi & TA, TB \\
\hline Closterium rostratum EHRENB. ex RALFS & Cloros & TA \\
\hline Cosmarium caelatum RALFS & - & $\mathrm{V}$ \\
\hline Cosmarium difficile LÜTKEM. & Cosdif & TA \\
\hline Cosmarium cf. furcatospermum WEST et G. S. WEST & Cosfur & TA \\
\hline Cosmarium cf. impressulum var. alpicolum $\mathrm{S}_{\mathrm{CHMIDLE}}$ & Cosimp & TA, TB, V \\
\hline Cosmarium notabile BRÉB. & Cosnot & TA \\
\hline Cosmarium obliquum var. obliquum NoRDST. & Cosobl & VS, V \\
\hline $\begin{array}{l}\text { Cosmarium obliquum cf. var. tatricum (GUTw.) KRIEGER et } \\
\text { GERLOFF }\end{array}$ & - & TB, VS, V \\
\hline Cosmarium pygmaeum ARCHER & Cospyg & $\mathrm{B}, \mathrm{TA}, \mathrm{TB}, \mathrm{VS}, \mathrm{V}$ \\
\hline Cosmarium quadratum RALFS ex RALFS & Cosqua & TA \\
\hline Cosmarium regnellii WILLE & Cosreg & TA \\
\hline Cosmarium sphagnicolum WeSt et G. S. WEST & Cossph & $\mathrm{B}, \mathrm{TB}, \mathrm{V}$ \\
\hline Cosmarium subquadrans var. minor SYMoENs & Cossub & $\mathrm{R}$ \\
\hline Cosmarium vexatum WEST & Cosvex & TA \\
\hline Cosmarium sp. & Cosspe & $\mathrm{B}, \mathrm{S}, \mathrm{R}, \mathrm{TA}, \mathrm{TB}, \mathrm{VS}, \mathrm{V}$ \\
\hline $\begin{array}{l}\text { Cylindrocystis brebissonii var. brebissonii (MENEGH. ex } \\
\text { RALFS) DE BARY }\end{array}$ & Cylbre & $\mathrm{M}, \mathrm{B}, \mathrm{S}, \mathrm{R}, \mathrm{TA}, \mathrm{TB}, \mathrm{VS}, \mathrm{V}$ \\
\hline Cylindrocystis gracilis I. HIRN & Cylgra & $\mathrm{S}, \mathrm{R}, \mathrm{TB}, \mathrm{V}$ \\
\hline Euastrum bidentatum NäGELI & Euabid & TA \\
\hline Euastrum binale var. gutwinskii (SCHмIDLE) HOMFELD & Euabin & M, B, S, TA, TB, VS, V \\
\hline Euastrum humerosum RALFS & Euahum & $\mathrm{TB}, \mathrm{VS}$ \\
\hline Euastrum insigne HaSSALl ex RALFS & Euains & $\mathrm{M}$ \\
\hline Euastrum subalpinum MessiK. & Euasub & TA, TB, V \\
\hline Haplotaenium minutum (RALFS) T. BANDO & - & VS \\
\hline cf. Mesotaenium degreyi TURnER & - & TA, V \\
\hline Mesotaenium endlicherianum NäGELI & Mesend & TA, TB, V \\
\hline
\end{tabular}


Table 3 Cont.

\begin{tabular}{|c|c|c|}
\hline Mesotaenium macrococcum (KüTz.) Roy et BISSET & Mesmac & $\mathrm{S}, \mathrm{R}, \mathrm{TA}, \mathrm{TB}, \mathrm{VS}, \mathrm{V}$ \\
\hline $\begin{array}{l}\text { Netrium digitus var. digitus (EHRENB. ex BRÉB.) ItZIGS. et Ro- } \\
\text { THE }\end{array}$ & Netdig & $\mathrm{B}, \mathrm{S}, \mathrm{TA}, \mathrm{TB}, \mathrm{VS}, \mathrm{V}$ \\
\hline Netrium digitus var. latum HusteDT & Netlat & $\mathrm{B}, \mathrm{TA}, \mathrm{TB}, \mathrm{VS}, \mathrm{V}$ \\
\hline Netrium oblongum (DE BARY) LÜTKEM. & Netobl & $\mathrm{B}, \mathrm{R}, \mathrm{TB}, \mathrm{VS}$ \\
\hline Penium exiguum West & Penexi & TA, TB \\
\hline Penium polymorphum (РeRTY) PeRTY & Penpol & TB, VS, V \\
\hline Staurastrum furcatum var. furcatum (EHRENB. ex RALFS) BRÉB. & Stafur & $\mathrm{R}, \mathrm{TB}$ \\
\hline Staurastrum furcatum var. aciculiferum (WeST) COESEL & Staaci & $\mathrm{M}, \mathrm{B}, \mathrm{R}, \mathrm{TA}, \mathrm{TB}, \mathrm{VS}, \mathrm{V}$ \\
\hline $\begin{array}{l}\text { Staurastrum hirsutum var. hirsutum (EHRENB.) ex BRÉB. in } \\
\text { RALFS }\end{array}$ & Stahir & TA, TB, VS, V \\
\hline $\begin{array}{l}\text { Staurastrum hirsutum cf. var. muricatum ([BRÉB.] BRÉB. ex } \\
\text { RALFS) KURT FöRST. }\end{array}$ & - & M \\
\hline Staurastrum margaritaceum (EHRENB.) MenEGH. ex Ralfs & Stamar & $\mathrm{M}, \mathrm{B}, \mathrm{S}, \mathrm{R}, \mathrm{TA}, \mathrm{TB}, \mathrm{VS}, \mathrm{V}$ \\
\hline Staurastrum punctulatum BRÉB. ex RALFS & Stapun & $\mathrm{TA}, \mathrm{V}$ \\
\hline Staurastrum simonyi HeIMERL & Stasim & TB, VS \\
\hline Staurodesmus extensus var. isthmosus (HeIMERL) Coesel & Stdext & TA, TB, VS, V \\
\hline Tetmemorus brebissonii (Menegh.) Ralfs ex Ralfs & Tetbre & $\mathrm{R}$ \\
\hline Tetmemorus laevis (KüTz.) RALFS & Tetlae & $\mathrm{TA}, \mathrm{TB}, \mathrm{V}$ \\
\hline Xanthidium antilopaeum var. laeve SCHMIDLE & Xanant & $\mathrm{R}$ \\
\hline
\end{tabular}

similar trend as the species mentioned above, but were found at more sites marked especially by higher Mg concentrations (mostly at the Trojmezí A bog), which is reflected in a deflection of their vectors (Fig. 3a).

After analysis of relationships between the physico-chemical factors and species composition of sample plots, we focused on comparison of whole bog localities. The RDA was used to reveal the similarity/dissimilarity of the eight peat bogs and to detect their distinctive species (not displayed). Locations of sample plots in particular mires were used as explanatory variables but their effect on species composition was not proved to be significant $(\mathrm{P}=0.056 ; 499$ Monte Carlo permutations). It corresponds well with results of the PCA ordination (Fig. 2a), which showed that desmid assemblages varied much more among different types of sample plots (e.g. lawns, pools) than among particular peat bogs. The location in particular bogs did not substantially influence the desmid flora; the species composition was primarily determined by the microhabitat type and local physico-chemical parameters.

Nevertheless, the RDA enabled to distinguish two different groups of peat bogs, more or less corresponding with geographic position of these bogs (see Fig. 1).

(a) The species-rich mires (24-33 desmid taxa) of the Šerák-Keprník NNR. They offer more favourable environment for the most desmids: especially several bog pools of various sizes and less acid water $(\mathrm{pH}>4)$. Actinotaenium silvae-nigrae, $A$. cf. spinospermum, Cosmarium cf. impressulum var. alpicolum, C. obliquum, Euastrum subalpinum, Mesotaenium endlicherianum, Penium polymorphum, Staurastrum hirsutum, Staurodesmus extensus var. isthmosus and Tetmemorus laevis seem to be characteristic for these mires. The analysis of respective desmid assemblages showed the high biological quality of these sites, harbouring several desmids considered to be rare and/or indicative of stable ecosystems (COESEL 1998; ŠŤAsTnÝ 2010). From this viewpoint, Trojmezí A and Trojmezí B appear to be the most interesting mires, as their nature conservation value reached grade 8 according to Coesel (1998). Especially the Trojmezí A bog can be clearly distinguished from all other mires due to the specific species 
composition related to higher $\mathrm{pH}, \mathrm{Ca}$ and $\mathrm{Mg}$ values. Eight desmid taxa (Euastrum bidentatum, Cosmarium vexatum, C. regnellii, C. quadratum, C. notabile, $C$. cf. furcatospermum, C. difficile, Closterium rostratum), prefering rather mesotrophic, moderately acid environment, were recorded only at this site in one pool (TA14), as previously shown in the PCA and RDA (Figs 2a, b, 3a, b).

(b) The species-poor bogs (9-16 desmid taxa) of the Praděd and the Rejvíz NNRs. Their low desmid diversity can probably be related to unfavourable values of some of the key factors influencing the species composition. In the case of the mires Máj and Slatě, we primarily consider the lower humidity and a lack of typical bog pools with submerged vegetation. Strong acidity $(\mathrm{pH}<$ 4 ) is most likely the main limiting factor in the Barborka bog and especially in the Rejvíz bog, which is the most acid mire under the study ( $\mathrm{pH}$ $=3.1-3.8)$.

The above mentioned comparison of bog localities suggests that particular mires may be rather perceived as complex factors, whose effects on desmid diversity are largely determined by their microtopography and physico-chemical conditions.

\section{Discussion}

Regarding the algological potential of acidic oligo-ombrotrophic mires (COESEL 1998, 2001), we can conclude that raised bogs in the Jeseníky Mts harbour rich and valuable desmid flora. Their desmid diversity is fully comparable with similar habitats in other mountain areas - e.g. the Jizerské hory Mts (ŠTĚPÁNKOVÁ et al. 2008), the Šumava Mts (Lederer \& Soukupová 2002). The most valuable assemblages were found at two bog sites of Trojmezí within the Šerák-Keprník NNR. It may be quite surprising, because they were affected by air dispersion of dolomitic limestone during the treatment of surrounding forests, last time in 1992 (RYBNíčEK 1997). Till now, it is still obvious on chemism of sample plots within the Trojmezí A (primarily TA14) showing the highest $\mathrm{pH}, \mathrm{Ca}$ and $\mathrm{Mg}$ values among all sites investigated (Table 1). Several remarkable desmids are concentrated here (Figs 3a, b) including taxa which are known to prefer rather mesotrophic, moderately acid environment (RŮŽIČKA 1977, 1981; COESEL 1983, 1985, 1991; Lenzenweger 2003). So, several years after the contamination, we can see that the typical oligotrophic desmid flora is still present (or regenerated) at the concerned plots and, moreover, the diversity of desmid assemblages might have become higher as a result of the past limestone treatment.

Another locality we want to discuss is the Rejvíz NNR. It is one of the largest and best preserved bog complexes in the Moravia region with a broad variety of biotopes: raised and transitional bogs, fen and waterlogged meadows, bog spruce and bog pine forests (KOLEKTIV AUTORŮ 2003; Š AFÁŘ 2003). Despite these characteristics, we found a seemingly low number (16) of desmid taxa here. However, this amount only refers to one investigated part of the vast complex - it was the central raised bog area with the Great Moss Lake, adjacent bog pine stand and one transitional plot. As mentioned above, these sites are characterized by very low $\mathrm{pH}$; moreover, the plots within the bog pine forest may be partially influenced by shading and low water table elevation (to -20 $\mathrm{cm})$. Especially the strong acidity is the limiting factor for many organisms. It is well known that peat bogs with similarly low $\mathrm{pH}$ values are often inhabited by a very few desmid taxa (e.g. LEDERER 1999; NovÁKovÁ 2003; ŠEJNOHOVÁ et al. 2003). Considering these facts, the 16 desmid taxa is a relatively high number for the central part of the Rejvíz NNR. Some rare and/or ecosystem stability indicating demids are also involved in this amount. Thus, we think the desmid flora corresponds with the generally pronounced uniqueness and biological value of the locality and desmid diversity of the whole bog complex may be much higher than we found now.

The analysis of desmid distribution in relation to physico-chemical variables surprisingly showed a very weak influence of electric conductivity (Fig. 3a; Table 2). In many studies dealing with desmid (algal) ecology in peat bogs, the effect of conductivity is presented as much stronger and often also more or less negatively correlated with effect of $\mathrm{pH}$ (e.g. LEDERER \& SouKuPOVÁ 2002; NovÁKOVÁ 2005; ŠTĚPÁNKOVÁ et al. 2008). Our finding can be explained by two facts. (I) We analysed conductivity values corrected for the effect of hydrogen ions, i.e. after subtraction of conductivity caused by $\mathrm{H}^{+}$(Sıörs 1952). This correction gives lower values and decreases the correlation with $\mathrm{pH}$. (II) Conductivity values of investigated plots created rather a short gradient probably insufficient to show the potential effect of 
this factor. Thus, in this case, species composition of desmid assemblages was influenced much more by concentrations of particular ions (especially $\mathrm{Mg}^{2+}$ ) than by the electric conductivity (i.e. total amount of dissolved ions).

Among all chemical substances measured and statistically tested, the $\mathrm{Pb}$ content appeared as the most important factor influencing the species composition (Fig. 3a; Table 2). However, we should make a comment on this result to prevent the potential overestimation of $\mathrm{Pb}$ effect. Concentrations of metallic elements such as $\mathrm{Pb}$, $\mathrm{Fe}, \mathrm{Mn}$ or $\mathrm{Al}$ are known to be highly variable in time and space and dependent on the actual water table elevation (RYBNíčEK 1997, 2003). Also our measurements show that the $\mathrm{Pb}$ content can fluctuate even in a range of several tens $\mu \mathrm{g} .1^{-1}$ during one year at the same plot (unpublished results). As the statistical evaluation by the RDA was related only to the data set derived from the sampling in summer 2008, we can not corectly assess the relationship between $\mathrm{Pb}$ and desmid distribution. Thus, further monitoring of this metallic element is required.

Desmid distribution among the investigated plots was related to 18 physico-chemical factors in RDA (Figs 3a, b). This relatively high number of important environmental variables explained just $73 \%$ of the species variation. It raises the question, what other factors may participate in the remaining amount of the variation. We particularly think about following: a/ influence of neighbouring sample plots (mentioned previously); $\mathrm{b}$ / phytocenological characteristics (reflecting the successional history of particular plots); c/ factors of island biogeography (especially size and mutual position of the respective bogs). From the list above, we would like to discuss the potential influence of phytocenological characteristics. Within the bogs of the Praděd and the Šerák-Keprník NNRs, RYBNí̌̌EK (1997) recognized eight basic vegetation types (subassociations) representing a successional series (see Material and methods). It is well known that these vegetation types are correlated with some physico-chemical variables, primarily with water table elevation (RYBNíčEK 1997) which is a key factor for desmid distribution. We suppose the pure effect of vegetation type was not very strong. But in some cases, it may be a useful tool for explanation of species composition within some investigated plots. The lawn site M3 can serve as a suitable example. In the RDA diagram (Fig. 3b), displaying the plots only according to the species variation explainable by the physico-chemical factors, this site is placed within the group of other lawns quite clearly. On the contrary, in the PCA diagram (Fig. 2a), where investigated plots were ordered according to the entire species variation, M3 is placed somewhat closer to the group of pools. Moreover, the DCA (not displayed) ordered this plot directly among the pool-samples. Vegetation of M3 classified as Drepanoclado fluitantis-Caricetum limosae subas. sphagnetosum capillifoliae represents a terminal successional stage of bog pools - after their terrestrialization (RYBNíČEK 1997). This successional history may be reflected in the species composition of the respective plot, which still retains some features of pools: absence/very rare occurrence of Actinotaenium silvae-nigrae var. parallelum and $A$. pinicolum (desmids typical for lawns), remnants of Euastrum insigne, Staurastrum furcatum var. aciculiferum and $S$. hirsutum (desmids typical for pools).

\section{Taxonomical Part}

\section{Results and Discussion}

During our study in the Jeseníky Mts, we found several desmid taxa remarkable for their rare occurrence and/or morphological variation. These finds are discussed in the text below.

\section{Actinotaenium pinicolum Rosa (Fig. 4a)}

(L.: 10-20 $\mu \mathrm{m}$, B.: 5-7.5 $\mu \mathrm{m}$ )

The species was described for science by Rosa (1959), after being detected among the edaphon in the pine-woods in South Bohemia (Czech Republic). During the following three decades, no other localities were recorded and the species was generally considered very rare in Europe (RỦžIČKA 1981; Coesel et al. 2006). Later it was found by KOUwETs (1988) in very low numbers in two small dessicating bog-pools in the French Jura. Coesel et al. (2006) recorded it on a dried Sphagnum hummock as a new species for the Netherlands. The most recent finds in the Czech Republic were made in several bog-lawns in the Jizerské hory Mts (ŠTĚPÁNKOVÁ et al. 2008).

In the Jeseníky Mts, we recorded the species at all the localities investigated with a distribution pattern suggesting a strong preference for subaerial microhabitats - abundant at Sphagnum lawns, rare in pools (Figs 2a, b, 3a), fully corresponding with the finds mentioned 
above. Within these populations, a broad morfological variability was displayed. The cell shape and dimensions changed continuously from the typically developed individuals, as presented e.g. in RỦŽǏČKA (1981), to very small forms with a somewhat simplified shape. Kouwets (1988) found only specimens considerably smaller (12$14.5 \times 5.5-6 \mu \mathrm{m})$ than was earlier reported by RosA (1959) and RŮŽIČKA (1981) (16-23 × 7-9 $\mu \mathrm{m})$. As he studied only bog pools and noted just a few cells, a survey of broader variability was less probable. Now, we have recorded a wider variation range of Actinotaenium pinicolum at the same time and place. In the Slatě mire, two individuals were observed forming a globular zygospore with rounded conical protuberances, fitting the description given in RŮžIČKA (1981).

Besides the discussed area, the desmid was also identified during occasional sampling of the transitional bog Skřítek (the Jeseníky Mts) and a small bog on alpine pasture (Parco Nazionale dello Stelvio, North Italy) (ŠTĚPÁNKOVÁ, unpublished results). Thus, the recent observations support the thought of RỦžıČKA (1981), that $A$. pinicolum may be a more common element of bog microflora than previously expected.

Cosmarium cf. furcatospermum WEST \& G.S. WEST (Fig. 4c)

(L.: 19-20 $\mu \mathrm{m}, \mathrm{B} .: 15-16.5 \mu \mathrm{m}$ )

The species, known mainly from moderately acid, mesotrophic habitats, is rare in central Europe (Coesel 1998; Gutowski \& Mollenhauer 1996; LENZENwEgER 2003). The database of cyanophytes and algae of the Czech Republic (PoulíčKová et al. 2004) includes only four historical records of Cosmarium furcatospermum, two of them from spring areas in the Jeseníky Mts (RŮžIČKA 1957; RYBNíČEK 1958). Recently, it was only reported by ŠŤASTNÝ (2010).

We found the species in one sampling plot of the Trojmezí A bog characterized by higher $\mathrm{pH}, \mathrm{Ca}$ and $\mathrm{Mg}$ values (Figs 3a, b; Table 1). Our findings correspond well to the habitat type given e.g. by WURM \& KRISAI (1993) as well as to ecological characteristics and drawings presented in LenZenweger $(1999,2003)$. However, slight morphological differences can be detected when comparing these with drawings made by COESEL (1991) or West \& West (1908). Thus, it is possible that there are some inconsistencies in taxonomy of this species in related scientific literature. A review of this problem will be required, including a detailed study on morphological variation and ecology of the species in question.

Cosmarium notabile BRÉB. (Fig. 4b)

(L.: 28-31.5 $\mu \mathrm{m}$, B.: $20 \mu \mathrm{m}$ )

Cosmarium notabile seems to prefer slightly acid, oligo-mesotrophic habitats of sub-aerial character (COesel 1998; ŠŤASTnÝ 2010). It was generally considered very rare in central Europe and often presented only as var. transiens INSAM \& KRIEGER (Coesel 1991; Lenzenweger 2003). However, a recent extensive investigation made by ŠŤASTNÝ (2010) proved its occurrence at 13 localities within the Czech Republic, suggesting that the species is more wide spread than previously thought. As it primarily inhabits less studied biotopes such ephemeral pools, ditches or wet rocks, it may be often overlooked (ŠŤASTNÝ 2008).

During our study, we repeatedly recorded this alga at the Trojmezí A bog. It was scattered throughout one sampling site (Figs 2a, b) which comprised of a small pool with adjacent Sphagnum growth, well corresponding with habitat types mentioned above.

\section{Cosmarium obliquum cf. var. tatricum (GuTw.)} Krieger \& GerlofF (Figs 4g, h)

(L.: 15-20 $\mu \mathrm{m}$, B.: $12.5-14 \mu \mathrm{m}$ )

The occurrence of this alga has only rarely been reported from Europe, especially from acid oligotrophic mires in montane regions (e.g. JoHN et al. 2002; LenZenweger 2003; Martello cf. 2003). Compared with larger individuals (25-29 $\times 20-22 \mu \mathrm{m}$ ) of the more spread type variety, it is characterized by its small cell size $(11-12 \times 10$ $11 \mu \mathrm{m}$ ), flat truncate apex and more constricted cell-sides (LENZENWEGER 1999).

In the course of our investigation, typical specimens of the nominal variety of $C$. obliquum were collected $(24-27.5 \times 21.5-22.5 \mu \mathrm{m})$. Besides these, obviously smaller forms with very slightly concave apex were also encountered - in some cases together with the nominal variety at the same plot, and/or separately. The dimensions (especially length), are somewhat larger than given by LENZENWEGER (1999), but corresponding well to a record from Italy $(18 \times 16 \mu \mathrm{m})$ made by Martello (cf. 2003). Considering the cell size and apex shape, it appears that there exists an intermediate type between nominal var. and var. tatricum. This raises the question, that if the variation range of $C$. obliquum may be much broader than usually considered (even as far as var. 
tatricum is involved) or if true intraspecific taxa really exist, characterised by well distinguished size-categories based e.g. on different ploidy levels (KASAi \& ICHIMURa 1987; Kouwets 1988).

\section{Cosmarium subquadrans var. minor Symoens} (Figs 4i, j)

(L.: 12.5-16.5 $\mu \mathrm{m}, \mathrm{B} .: 15-19 \mu \mathrm{m}$ )

Coesel \& Meesters (2007) regard this alga as very rare in the Netherlands. Judging from its absence on many national check-lists (e.g. Gutowski \& Mollenhauer 1996; KostKeviciene et al. 2003; LENZENWEGER 2003), it is probably very rare in whole Europe. Also in the Czech Republic, no historic reports on this taxon are available (PoulíčKovÁ et al. 2004). Recently, it was found by ŠřASTNÝ (2010) at a few remarkable bog localities, such as the Swamp Nature Reserve (North Bohemia).

During our study, we repeatedly recorded numerous individuals at a site where the characteristics resemble the environment of the Swamp mire - very acid transitional bog covered with extensive Sphagnum growths, adjacent to Pinus rotundata stands.

\section{Euastrum subalpinum Messik. (Fig. 4f)}

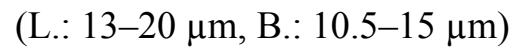

The species occurs rather rarely or scattered in Europe, especially in moderately acid, mesotrophic wetlands (RƯŽIČKA 1981; COESEL 1985; GUTOWSKI \& Mollenhauer 1996; KostKeviciene et al. 2003; LENZENWEgER 2003). Similarly, rather sparse records have been published from the territory of the Czech Republic (RỦžIČKA 1973; ŠŤASTNÝ 2008, 2009).

In the Jeseníky Mts, Euastrum subalpinum was recorded in several shallow pools between the Keprník and the Vozka peaks, where it appears to retain stable populations. A broad morphological variability was observed. Cell dimensions and length/breadth ratio (1.20-1.46) continually changed across the extent of both nominal variety and var. crassum Messik. as well (compare e.g. with RŮŽIČKA 1981; LENZENWEGER 1996). This data supports the earlier opinion of RŮŽIČKA (1981), that var. crassum may just represent a marginal diversion in the frame of the nominal variety (and as such lose its taxonomical relevance).
Penium exiguum West (Fig. 4e)

(L.: 31.5-68 $\mu \mathrm{m}$, B.: $12-12.5 \mu \mathrm{m})$

The species, characteristic of acid, oligotrophic Sphagnum bogs, is thought to be scattered or rare in Europe (RỦŽIČKA 1977; CoESEL 1982; GUTOWSKI \& Mollenhauer 1996; KostKeviciene et al. 2003). Similarly, only a few recent records have been made in the Czech Republic, coming from mire complexes of exceptional biological value: the Břehyně-Pecopala NNR (ŠŤASTNÝ 2005), peat bogs in the Jizerské hory Mts Protected Landscape Area (ŠTĚPÁNKOVÁ et al. 2008) and the Swamp Nature Reserve (ŠŤASTNÝ 2009). The latter author considers the species very rare in the Czech Republic (ŠŤASTNÝ 2010).

We repeatedly found a rich population of Penium exiguum in a shallow pool at the Trojmezí A bog. As the above mentioned sites are all localized in north Bohemia, our find can be regarded as the first one in the Moravia region.

\section{Xanthidium antilopaeum var. laeve SCHMIDLE} (Fig. 4d)

(L.: 70-75 $\mu \mathrm{m}$, B.: 57.5-62.5 $\mu \mathrm{m}$ )

Xanthidium antilopaeum var. laeve obviously is much less wide spread in Europe than the type variety of the species (Coesel 1994; GutowsKI \& Mollenhauer 1996; Lenzenweger 2003). Also in the Czech Republic, it is considered as a rare taxon (PoulíčKovÁ et al. 2004; ŠŤASTNÝ 2010). It appears well distinguished from the type variety by a widely open sinus, rounded at the top, and by the lack of a middle cell-wall ornamentation (LENZENWEGER 1997).

In the Jeseníky Mts, we recorded the taxon only in the shore-zone of the very acid lake at the Rejvíz bog (Figs 3a, b). Within the population, a remarkable variability of cell-wall sculpture was noticed repeatedly, in different seasons. Besides the typical smooth-surfaced individuals, a large number of specimens were bearing a distinct node (looking like a strong reduced spine) in the semicell-centre.

\section{Conclusions}

During our study, a remarkably broad morphological variation was observed within several desmid populations. Besides some examples discussed above, it also refers to several other taxa. On the one hand, some species (e.g. Euastrum subalpinum, Netrium digitus, 
Staurastrum furcatum) showed broad continuous variation including morphotypes which have been traditionally presented as separate varieties or even species. It corresponds well with critical opinion of other authors (e.g. RŮŽIČKA 1977; Kouwets 1988; Coesel \& Krienitz 2008) that many redundant desmid taxa were described on the basis of only one or a very few specimens. Then, excessive taxonomical value was attached to small morphological differences or anomalies without detailed knowledge of phenotypic variation in concerned species. On the other hand, we also found some examples of discontinuous variation in the frame of some taxa: well distinguished sizecategories (Cosmarium obliquum); developing of extra spines (Xanthidium antilopaeum var. laeve); different degrees of radiation (bi- and triradiate forms of Cosmarium pygmaeum and $C$. sphagnicolum). If such morphological differences become fixed genetically and maintained in stable populations, they can be classified as true separate taxa (e.g. varietes) as thinks Kouwets (1988).

In many aspects, our findings closely resemble the observations made by Kouwets (1988) in mountain bogs in the French Jura. He states broad morphological variation may be induced by extreme environmental factors: in shallow bog pools, algae are exposed to periodical dessication, sharp temperature fluctuations and high UV radiation. It is probable that such conditions stimulate microevolutionary processes. Various mutations, like changes in ploidy level, may be induced more frequently here and then be reflected in the discontinuous morphological variation within the concerned taxa as mentioned above. Coesel \& KRIENITZ (2008) pointed out that desmids are haploid organisms, so most mutations are immediately expressed in the phenotype and their predominant clonal reproduction may readily result in the formation of microspecies. From this viewpoint, shallow periodical bog pools in mountain (especially alpine) areas, where the $\mathrm{UV}$ radiation is stronger, might be considered as examples of an „evolutionary soup“.

\section{Acknowledgement}

We are grateful to Mgr. Martin Kočí, Ph.D. for leading the field works in the Jeseníky Mts, to Doc. Mgr. Michal Hájek, Ph.D. and Mgr. Kateřina Kintrová, Ph.D. (MU Brno) for providing some ecological data. We also would like to thank to the editorial consultant for his valuable comments on our manuscript and to Mgr. Steven Morris for english language corrections. Our research was supported by projects GACR 206/08/0389 and PdF_2011_047 and PrF_2011_003.

\section{References}

BezděK, A.; Jaroš, J. \& Spitzer, K. (2006): Spatial distribution of ground beetles (Coleoptera: Carabidae) and moths (Lepidoptera) in the Mrtvý luh bog, Šumava Mts (Central Europe): a test of habitat island community. - Biodivers. Conserv. 15: 395-409.

Charman, D.J. (2002): Peatlands and environmental change. - 301 pp., John Wiley \& Sons Ltd., Chichester.

Coesel, P.F.M. (1982): De Desmidiaceeën van Nederland, Deel 1, Fam. Mesotaeniaceae, Gonatozygaceae, Peniaceae. - 33 pp., KNNV, Hoogwoud.

Coesel,P.F.M.(1983):DeDesmidiaceeënvanNederland - Sieralgen, Deel 2, Fam. Closteriaceae. - 50 pp., Wetenschappelijke Mededelingen KNNV, Hoogwoud.

Coesel, P.F.M. (1985): De Desmidiaceeën van Nederland, Deel 3, Fam. Desmidiaceae 1. - 70 pp., KNNV, Hoogwoud.

Coesel, P.F.M. (1991): De Desmidiaceeën van Nederland, Deel 4, Fam. Desmidiaceae 2. - 89 pp., Stichting Uitgeverij KNNV, Utrecht.

Coesel, P.F.M. (1994): De Desmidiaceeën van Nederland, Deel 5, Fam. Desmidiaceae 3. - 53 pp., Stichting Uitgeverij KNNV, Utrecht.

Coesel, P.F.M. (1997): De Desmidiaceeën van Nederland, Deel 6, Fam. Desmidiaceae 4. - 93 pp., Stichting Uitgeverij KNNV, Utrecht.

Coesel, P.F.M. (1998): Sieralgen en Natuurwaarden. 56 pp., Stichting Uitgeverij KNNV, Utrecht.

Coesel, P.F.M. (2001): A method for quantifying conservation value in lentic freshwater habitats using desmids as indicator organisms. Biodivers. Conserv. 10: 177-187.

Coesel, P.F.M. (2003): Desmid flora data as a tool in conservation management of Dutch freshwater wetlands. - Biologia 58: 717-722.

Coesel, P.F.M. \& Krienitz, L. (2008): Diversity and geographic distribution of desmids and other coccoid green algae. - Biodivers. Conserv. 17: 381-392.

Coesel, P.F.M; Meesters, K.J. \& Schulp, H.H.F. (2006): Subatmofytische sieralgsoorten, nieuw voor de Nederlandse flora. - Gorteria 31: 137141.

Coesel, P.F.M. \& MeEsters, K.J. (2007): Desmids of the Lowlands. Mesotaeniaceae and Desmidiaceae of the European Lowlands. - 351 pp., KNNV Publishing, Zeist.

FISCHER, R. (1924): Oekologische Skizzen zur Algenflora des mähr.-schles. Gesenkes. - 
Schriften für Süßwasser- und Meereskunde 7: $1-20$.

FischeR, R. (1925): Oekologische Abhandlung zur Algenflora des mähr.-schles. Gesenkes. Verhandlungen des naturforschenden Vereines in Brünn 59: 3-11.

Gutowski, A. \& Mollenhauer, D. (1996): Rote Liste der Zieralgen (Desmidiales) Deutschlands. In: Ludwig, G. \& Schnittler, M. (eds): Rote Liste Gefährdeter Pflanzen Deutschlands. Schriftenreihe für Vegetationskunde 28. - pp. 679-708, Bundesamt für Naturschutz, BonnBad Godesberg.

John, D.M.; Whitton, B.A. \& Brook A.J. (eds) (2002): The Freshwater Algal Flora of the British Isles: An Identification Guide to Freshwater and Terrestrial Algae. - 697 pp., Cambridge University Press, Cambridge.

Kasai, F. \& Ichimura, T. (1987): Stable diploids from intragroup zygospores of Closterium ehrenbergii Menegh. (Conjugatophyceae). - J. Phycol. 23: 344-351.

Kolektiv AUTORŮ (2003): Plán péče o Chráněnou krajinnou oblast Jeseníky na období 20032013, Rozborová část. - 198 pp., Správa CHKO Jeseníky, Jeseník.

Kostkeviciene, J.; Briskaite, R.; Bakunaite, J. \& JAKIMAVICIUTE, I. (2003): Desmids (Chlorophyta, Desmidiales) from Lithuania. - Biologia 58: 685-695.

Kouwets, F.A.C. (1988): Remarkable forms in the desmid flora of a small mountain bog in the French Jura. - Cryptogamie, Algologie 9: 289309.

Lederer, F. (1999): Algal flora of the Červené blato peat bog (Třeboň Basin, Czech Republic). Preslia 70: 303-311.

Lederer, F. \& SoukupovÁ, L. (2002): Biodiversity and ecology of algae in mountain bogs (Bohemian Forest, Central Europe). - Algological Studies 106: 151-183.

LENZENWEGER, R. (1996): Desmidiaceenflora von Österreich, Teil 1. - 162 pp., J. Crammer, Stuttgart.

Lenzenweger, R. (1997): Desmidiaceenflora von Österreich, Teil 2. - 216 pp., J. Crammer, Stuttgart.

LENZENWEGER, R. (1999): Desmidiaceenflora von Österreich, Teil 3. - 218 pp., J. Crammer, Stuttgart.

Lenzenweger, R. (2003): Desmidiaceenflora von Österreich, Teil 4. - 87 pp., J. Crammer, Stuttgart.

Lhotský, O. (1949): Poznámka k floře Desmidiaceí Hrubého Jeseníku. - Časopis Vlasteneckého spolku musejního v Olomouci 58: 149-155.

Martello, G.V. (cf. 2003): Ricerche desmidiologiche nell' Altopiano del Cansiglio: Il Lamaraz.- 10 pp. (available at

http://digilander.libero.it/desmids/desmidiaceae/ pdf_scaricabili/lmz_testo.PDF).

Mitchell, E.A.D.; Charman, D.J. \& Warner, B.G. (2008): Testate amoebae analysis in ecological and paleoecological studies of wetlands: past, present and future. - Biodivers. Conserv. 17: 2115-2137.

NovÁkovÁ, S. (2003): Algoflóra rašeliništ' Českosaského Švýcarska. - Czech Phycology 3: 71-78.

NovÁkovÁ, S. (2005): Comparison of the algal flora in subalpine and montane mires in the Krkonoše Mts (the Giant Mts; Czech Republic). - Czech Phycology 5: 57-68.

PoulíčKovÁ, A.; Lhotský, O. \& Dřímalová, D. (2004): Prodromus sinic a řas ČR. - Czech Phycology 4: 19-33.

Rosa, K. (1959): Actinotaenium pinicolum species nova. - Preslia 31: 377-380.

RƯŽIČKA, J. (1957): Krásivky z prameništ’ na Malém Dědu (Hrubý Jeseník). - Časopis Slezského Musea 6: 108-121.

RŮŽIČKA, J. (1973): Die Zieralgen des Naturschutzgebietes, „̌Režabinec“(Südböhmen). - Preslia 45: 193-241.

RŮŽIČKA, J. (1977): Die Desmidiaceen Mitteleuropas, Band 1, 1. Lieferung. - 291 pp., E. Schweizerbart'sche Verlagsbuchhandlung, Stuttgart.

RŮŽIČKA, J. (1981): Die Desmidiaceen Mitteleuropas, Band 1, 2. Lieferung. - pp. 292-736, E. Schweizerbart'sche Verlagsbuchhandlung, Stuttgart.

RYBNíČEK, K. (1958): Krásivky pramenné oblasti Branné v Hrubém Jeseníku. - Přírodov. sbor. Ostravského kraje 19: 97-122.

RYBNíČEK, K. (1997): Monitorování vegetačních a stanovištních poměrů hřebenových rašeliništ' Hrubého Jeseníku - výchozí stav. - Př́roda 11: $53-56$.

RYBNíČEK, K. (2003): Sledování stanovištních a vegetačních změn na rašeliništích Jizerských hor a Jeseníků (Monitoring of habitat and vegetation changes in the Jizerské hory and Jeseníky Mts.). - In: PivníčKovÁ, M. (ed.): Sborník dílčích zpráv z grantového projektu VaV 610/10/00 ,Vliv hospodářských zásahů na změnu v biologické rozmanitosti ve zvláště chráněných územích“. Př́roda, suplementum. pp. 151-154, Praha.

SJöRS, H. (1952): On the relation between vegetation and electrolytes in north Swedish mire waters. - Oikos 2: 241-258.

ŠAfÁř, J. (ed.) (2003): Olomoucko. - 454 pp., Agentura ochrany př́rody a krajiny ČR, Praha; EkoCentrum, Brno.

Šejnohová, L.; ŠKaloud, P.; Neustupa, J.; Nováková, S.; Řezíčová, M. \& OŠlejŠKová, L. (2003): 
Řasy a sinice $\mathrm{z}$ rašeliništ', vodních toků, nádrží a aerických biotopů jižní Šumavy. - Czech Phycology 3: 41-52.

ŠřASTNÝ, J. (2005): Diverzita a ekologie krásivek ve vybraných oblastech České republiky. - 83 pp., Dipl. Thesis, Charles University, Faculty of Science, Prague.

ŠŤASTNÝ, J. (2008): Desmids from ephemeral pools and aerophytic habitats from the Czech Republic. Biologia 63: 888 - 894 .

ŠřAstNÝ, J. (2009): The desmids of the Swamp Nature Reserve (North Bohemia, Czech Republic) and a small neighbouring bog: species composition and ecological condition of both sites. - Fottea 9: $135-148$.

ŠŤAstnÝ, J. (2010): Desmids (Conjugatophyceae, Viridiplantae) from the Czech Republic; new and rare taxa, distribution, ecology. - Fottea 10: $1-74$.

ŠTĚPÁnKovÁ, J.; VAVRUŠKovÁ, J.; HAŠLER, P.; MAZALOVÁ, P. \& PoulíčKovÁ, A. (2008): Diversity and ecology of desmids of peat bogs in the Jizerské hory Mts. - Biologia 63: 891-896.

ter Braak, C.J.F. \& Šmilauer, P. (1998): Canoco references manual and user's guide to Canoco for Windows. - 353 pp., Centre of Biometry, Wageningen.

West, W. \& West, G.S. (1908): A Monograph of the British Desmidiaceae, Vol. III. - 274 pp., The Ray Society, London.

Wurm, E. \& Krisai, R. (1993): Schrenkenbühelmoos und Konradenmoos, zwei Fichtenmoore in den östlichen Zentralalpen. - Mitt. Abt. Bot. Landesmus. Joanneum Graz 21/22: 55-94.

(C) Czech Phycological Society (2012)

Received May 1, 2011

Accepted September 20, 2011 